\title{
Obituary
}

\section{Professor Alan Dyer, BSc, PhD FRSC C.Chem.}

\author{
Craig Williams* \\ School of Applied Sciences, University of Wolverhampton, Wolverhampton WV1 1LY, UK
}

Above all Alan was an enthusiast. As a young man he was a keen lacrosse player and cricketer and in later life he became involved in lacrosse administration, becoming co president of the English Lacrosse Association in 1995. In 1997 he was awarded the centurion award for services to Lacrosse. Alan was a keen bridge player and his $\mathrm{PhD}$ students knew that every lunchtime they would find him at University Staff House, playing bridge. He had an interest in geology and was a talented mineralogist; Roy Starkey will say more on this aspect of Alan's life. Alan was also a keen hiker and on many weekends the group and any visiting researchers such as Jörg Kärger and Bob Thompson and family would hike around the Peak District. He also shared a love of malt whisky with his oldest friend of over 50 years standing Lovat Rees. He was very active in the Royal Society of Chemistry; being chairman of the radiochemical method group 1982-1994 and in 1994 he was awarded an RSC silver medal. However for all these interests Alan will be most remembered for his work on Zeolites, founding the British Zeolite Association in 1977 with fellow zeolite workers, Lovat Rees, Barrie Lowe and Frank Leach.

Alan was born on $29^{\text {th }}$ March 1934 in Salford, the son of Colin and Florence Dyer. He gained his BSc with honours at the University of Sheffield (1954) and his $\mathrm{PhD}$ at Kings College, London (1958), finally being awarded a DSc by the University of Salford (1981). His academic life started in teaching at Wardley Grammar School, Worsley, Lancashire from 1957-1959. This was followed by an appointment as Lecturer at the Royal Technology College, Salford from 1959-1961. In 1961 he took the post of Senior Lecturer at the Royal College of Advanced Technology, Salford until 1964, when the college was made a University. He remained a Lecturer at the University of Salford until 1970, when he was promoted to Senior Lecturer and in 1985 he was promoted to Reader. Alan became Professor of Chemistry at Salford in 1997 and remained in this post until he retired; he was also a visiting Professor for Loughborough University.

Alan was a consultant to numerous companies including BNFL, Alcan Chemicals, SDS BioTech, ICI and of course Laporte. These companies funded a large number of research projects, including my own. He was also appointed technical director of the British Zeolite Company in 1994, where he worked with another good friend Bob Kent.

Alan married Dilys Patricia Groves on the $30^{\text {th }}$ August 1958, and had four children, Andrew, Fiona, Jennifer and Christopher. He died peacefully, in the early hours of $7^{\text {th }}$ September 2021; he will be very sadly missed by all who knew him.

\footnotetext{
*Author for correspondence: Craig Williams, Email: C.Williams@wlv.ac.uk Cite this article: Williams C. (2021) Professor Alan Dyer, BSc, PhD FRSC C.Chem. Mineralogical Magazine 85, 921-925. https://doi.org/10.1180/mgm.2021.88
}

\section{Memories of Alan}

My own first memory of Alan was in 1982. I was an undergraduate at Salford and had just finished a radiochemistry practical with Alan and another member of staff, Dr Bob Blackburn. As you leave the active side of Cockcroft Building you have to put your hands into a monitor. I duly did so and all hell broke lose, the alarms were screaming, then two men in full rubber suits and masks charged at me and whisked me away into the decontamination room where I stripped and they scrubbed me and sprayed me with EDTA solution for 30 minutes. On leaving the decontamination room both Alan and Bob were still there. Alan turned to Bob and said "I told you this would be needed one day; I just didn't think it would take 20 years!" After my BSc degree Alan took me on as a $\mathrm{PhD}$ student. The project involved using radiochemical tracers to look at diffusion in zeolites, so I worked in the active side of Cockcroft for my $\mathrm{PhD}$, and yes I did see that decontamination room one more time!

In 1984 Alan decided to do a natural zeolite hunting trip to NW Scotland and a small group of Open University and Salford University students went with him; we went up in two cars. The trip was so successful that the following year Alan had to take a mini bus up there and we met up with Barrie Lowe's research group, who were all travelling in Barrie's camper van (a tight squeeze, but Barrie had brought plenty of his home brew wine and very good it was) from Edinburgh University. It was on the first trip that Alan introduced me to malt whisky, and I have never looked back! These trips became an annual event and several of us, who had finished our $\mathrm{PhD}$ used to come back to just go on the trips. I only missed one, a trip to the Antrim Coast. In 1995 I was by then an established Senior Lecturer at Wolverhampton University and I took my own zeolite research group up to Skye to meet with Alan's group. Needless to say we all had a great time (see image from the trip).

Alan to me was my supervisor and mentor but most importantly my friend.

Craig Williams, Professor of Inorganic Chemistry, University of Wolverhampton, UK

The British Zeolite Association was more than just a special interest group of scientists - it was a family, and no-one made it more of a family than Alan. The first book I was directed to read by my supervisor Barrie Lowe was Alan's 'An Introduction to Zeolite Molecular Sieves'. As a very young and naive student, I remember attending my first ever BZA conference at Chislehurst in 1990 and being a bit overawed meeting Alan (the author of the book!). Alan was so nice and friendly, with a great sense of humour, it made me realise that these conferences weren't such scary places, and I immediately felt part of the zeolite community. Even when I stopped being actively involved in zeolites, I enjoyed sharing the 

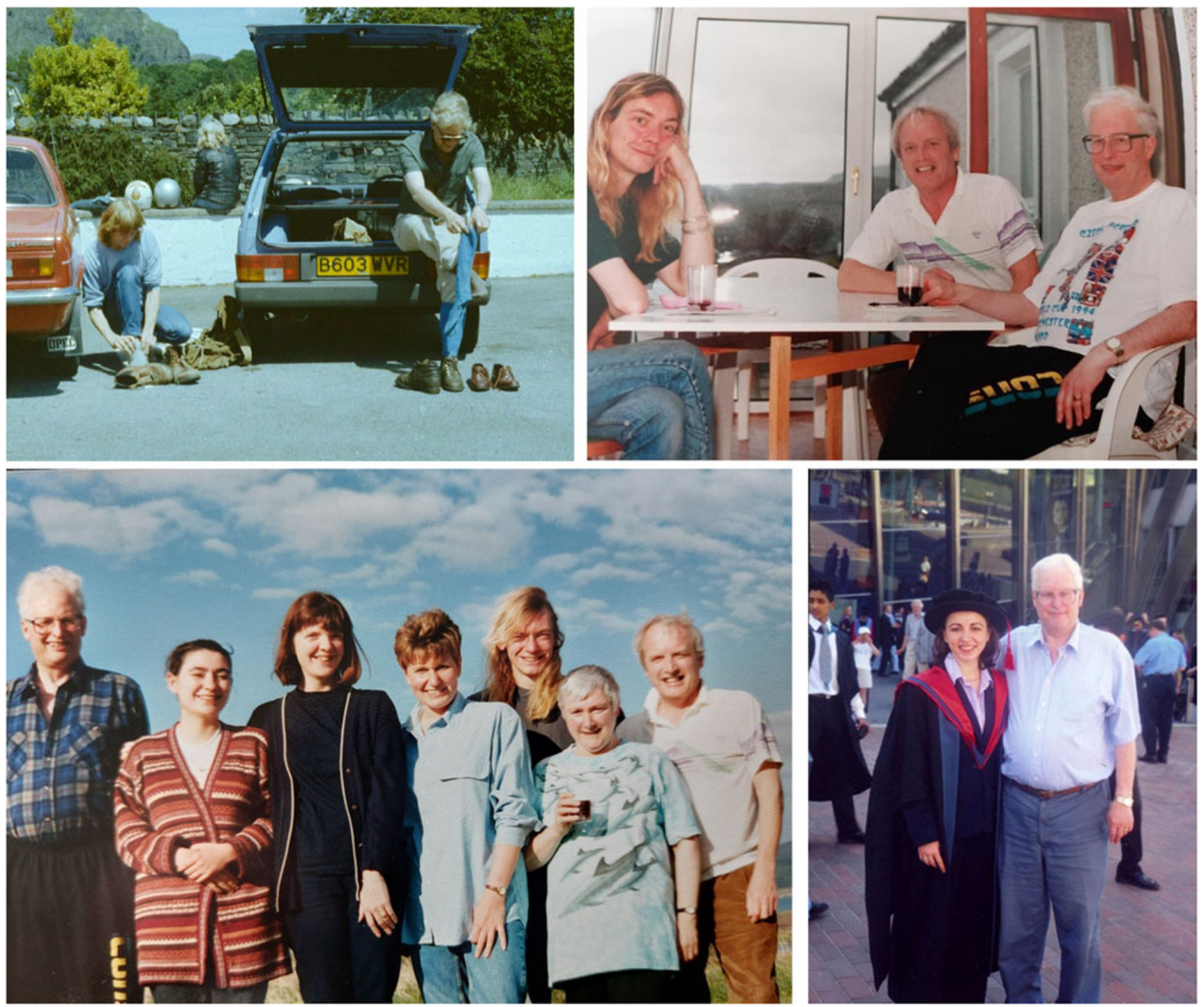

Top left: Craig Williams and Alan on a trip to the Peak District in 1984 (Photo courtesy of Jörg Kärger). Top right: Craig Williams, Bob Mooney and Alan relaxing after zeolite hunting on Skye 1996 (Photo courtesy Sue Hill). Lower left: Alan, Martina Gibbons, Sue Hill, Kay Latham, Craig Williams, Oneta Wilson and Bob Mooney (Photo: Sue Hill). Lower right: Alan and Lina AL Attar at Lina's Graduation Ceremony (15 July 2003).

occasional joke with Alan over email. I never quite lost the 'awe', and it still felt special to be communicating directly with Alan. He will be very much missed by the international zeolite family. Keith Franklin, British Zeolite Association President, 2003

Professor Alan Dyer will be remembered very fondly by all. He always had time for his students and friends, and they enjoyed his company. He showed them great care and kindness.

Alan was a great scientist and an inspiration to many. He is a great loss to the wider scientific community, and will be sadly missed. May he rest in peace.

Hassan Enamy and Oneta Wilson, PhD student, then Post Doc and PhD student

I'm 77yrs old and Alan I promise you was one of the very few people that has and will stay in my mind. He helped my company to introduce Zeoclere - zeolites to the swimming pool industry. Not only did he do that but the spin off over 20 years has enabled many underprivileged people in South Africa to have employment. A true Gentleman - a very lovely person. I have to admit, that this is being typed with tears in my eyes.

Bob Kent, Founder of the British Zeolite Company (now MSI)

I was Alan Dyer's last PhD student at the University of Salford (1999-2003). Alan's expert advice, kindness and supervision helped me to obtain my $\mathrm{PhD}$, receiving high praise from those who attended my viva. I solely attribute my success in the viva to Alan and his guidance and loving heart. After returning to Damascus, my home city, in 2003, I took up a position in AECS and Alan and I kept in regular contact ever since. Alan was like a father, brother and dear friend and memory of his kindness will always be my inspiration and motivation through difficult times.

I will greatly miss Alan and may his memory also live on in others he helped. Rest in peace.

Lina Al-Attar (Prof., Dr., MSc., BSc.)

I want to begin my tribute by also thanking Craig Williams so much for coordinating this tribute to Alan Dyer - it is clear 
that he is indeed missed very deeply by all his colleagues and certainly not least by me. My wife Patricia and I have been privileged to know Alan and Dilys for over fifty years - I was one of his earliest research students. In my case I first met him when I was an undergraduate student at Salford completing my Grad RIC and living in university accommodation at Joule Hall of Residence (single sex then - no girls allowed in your room after $10 \mathrm{pm}$ !). Alan was the resident Warden, living there with Dilys and his rapidly growing young family. I also had contact with him academically, in that he gave us a full lecture course on solid state chemistry, introducing us to the mysteries of Bravais lattices, mineralogy, nucleation processes in synthesis, topotaxy, the distinction between topology and structure and (surprise, surprise....) a group of minerals called zeolites! At the time, I must confess that I wasn't turned on at all by the subject of solid state chemistry, but I was hugely impressed by his obvious enthusiasm for zeolites in particular and his keenness to share that enthusiasm. But it wasn't this that first led me to respect him and come to admire him - it was something that happened not long after I had taken up residence in Joule Hall, long before we had interacted in the university itself. One evening I was walking through the corridors to join everyone for the evening meal in the refectory when suddenly on turning a corner I saw coming towards me the 'boss man' of Joule Hall himself; as he passed me Alan smiled at me and greeted me personally by name! I was gratified and astonished, even more so when I discovered that he knew the names of all my dozen or so mates in Hall, so soon after we had all arrived. It was obvious that Alan had taken the trouble not only to learn our names but also to be acquainted with us at a personal level. I was very impressed!

Through that year in Joule Hall, I learnt from Alan many other lessons on how to manage people and I hope that subsequently I have put these into practice. The late 1960s was a time of unrest and student protest in universities and Salford was no exception. I remember when we had had a riot one evening over the quality of the refectory food and Alan was called by the domestic staff to come and restore order (no mean feat when you are facing 100 young lads voicing protests!). He stood his ground firmly yet coolly, with no pomposity, shouting or threatening. I am not proud to admit that I was one who was prominent in my protestations but soon all was calm and he promised to look into our complaints, which he duly did. Shortly after this incident I happened to meet him again in the corridor; again, he just smiled at me and personally greeted me as though nothing untoward had happened. I felt deeply ashamed. Ten years later things had gone full circle: by then I was a Lecturer and Deputy Warden of two Halls of Residence at City University in London, resident with Patricia and our two children and in charge of 315 male and female students when on duty; I often had cause to remember with thanks the many lessons I had learnt by example from Alan when faced with challenging or fraught situations.

Up to now I have dwelt on some very early encounters I had with Alan; please allow me to describe how I came to be one of Alan's PhD students at Salford and why I value so much his influence on my subsequent training and career, which has been truly enormous. I was intending to return to working at BP Chemicals after completion of my Grad RIC studies but I was fortunate enough to excel in my final exams and was therefore offered an unconditional $\mathrm{PhD}$ studentship supported by the Science Research Council (later to become SERC) via a much coveted SRC Departmental Quota Award. I was thrilled and gratefully accepted the offer with alacrity. In those days the very few quota awards were entirely within the gift of the Head of Department (Prof Glyn O Phillips - sadly, after a very distinguished career he also died recently, in 2020 aged 92); he was very helpful to me and emphasised that I was free to choose whatever research topic I wanted. He told me to talk to whoever I wanted within the Department. However, there were strong caveats attached to this: he indicated that he hoped I would work directly for him and the topic should be related to physical aspects of biological chemistry. I was somewhat perturbed by this and I regret to say I didn't take the caveats as seriously as I should have done. I took his advice at face value and shopped around; obviously I included Alan in the shortlist of people to whom I should talk. After completing my survey, I was nonplussed. I knew what I didn't want to do - that was organic synthesis never a strong point in my skills base I'm afraid! Above all I loved physical chemistry but beyond that I had no strong preferences, although Glyn Phillips' ground-breaking work on the solvated electron and pulse radiolysis was potentially very interesting. Finally, I made a decision - I decided I wanted to work for Alan. I cannot emphasise too much that this decision was not made because I had suddenly fallen in love with zeolite chemistry! Rather, I made it on the basis of what I had already seen in Alan as a person - someone who was a thoroughly approachable tutor and who placed the interests of his students high on his list of priorities. As regards research topics, I felt that these could be sorted out later. I therefore knocked on Alan's door and told him that I would like to work with him on zeolites. He was clearly delighted and told me to leave it with him; he would talk to Prof Phillips. I went away content: how little did I understand the vagaries of academic department politics and the power that professors could wield in those days!

Shortly after this I received a message from Prof Phillips' secretary that I was wanted urgently in his office. The curt form of delivery of the message clearly indicated that something was very wrong. It was with a sinking feeling that I knocked on the door and entered Glyn's office. It was to be a meeting I vividly remember. My sinking feeling was prescient: it was clear that he was incandescent with anger. However, he and I were not alone. Sitting to one side was Alan - he was calmly smoking his pipe with his favourite tobacco in it - a very pleasant blend which I will always associate with him. It was immediately clear to me that Alan had already borne the brunt of Glyn's fury (I understood later that he had been accused of deliberately 'pirating' me away from Glyn). I realised that in my enthusiasm and perhaps arrogance I had inadvertently and naively 'dropped Alan right in it', so to speak. It was apparent that although Alan was clearly not annoyed with me, nevertheless it was now down to me to do what was necessary to help straighten things out. Glyn turned to me and said, "I have already made it very clear to Dr Dyer my strong displeasure over what has happened. He tells me that you want to work with him on zeolites - is that true and was that your decision alone?" I affirmed truthfully that this was indeed the case and apologised to Glyn for my lack of etiquette in not going to him first with my decision. He then looked closely at me and finally said, "Very well, I agree in principle, but only in principle at this point. Should I finally agree that you can keep the quota award, you will also work for me for $50 \%$ of the time and before I confirm my agreement I require you to complete a detailed task for both of us. Dr Dyer and I now want you to go away and come back to us both in six weeks without fail with a detailed formal research proposal covering three years for two interlinked projects, one on zeolites 
and one on biological chemistry, which fits with this 50:50 time allocation. We will then assess jointly whether your research proposal is acceptable to us". With this he terminated the meeting abruptly and Alan and I left Glyn's office together, with me in a state of shock, and we went to Alan's office. Once there, I apologised profusely to Alan but first and foremost he went out of his way to assure me that as far as he was concerned I had nothing whatever to apologise for. However, he then emphasised to me the potential seriousness of the situation and however much he wanted to help, the proposal content and writing was to be my responsibility and mine alone. Concerning the zeolite component he said he would direct me to all the literature he could as I developed and wrote the zeolite proposal and he would help me with understanding any technical problems I might encounter but for the biological chemistry proposal I had to be entirely on my own. I understood where he was coming from and I appreciated not just his generous tacit support for me but also something far more significant - he was placing total trust in me to deliver the goods on behalf of him as well as me and by the very tight deadline that Glyn had set. I knew I must honour the faith he was showing in me and I went away from his office to work on the proposal feeling calmed, yet excited and utterly determined to deliver. Alan had done to me what any good tutor should do to his or her student. I will never forget what he did for me that morning - thank you, Alan!

To cut a long story short, I remembered that Glyn had told me how excited he was about the recent X-ray structural elucidation of lysozyme to a resolution of a fraction of a nanometre. Unfortunately lysozyme was not suitable for my studies as it was neither a metal-activated enzyme nor a stoichiometric metalloenzyme. Serendipitously I then discovered in current literature that the tertiary structure of carboxypeptidase A had just been elucidated to high resolution by $\mathrm{x}$-ray diffraction, in this case a metalloenzyme containing exactly what I needed - a labile tetrahedrally coordinated zinc at its active site. Other recent research had already shown that it was readily possible to replace in aqueous phase the labile zinc by octahedrally coordinated cobalt, thus changing the native catalyst's proteolytic activity to an esterase one. So why not see if similar exchange would take place in the crystalline phase in an analogous way to zeolites and whether the catalytic activity could be maintained and 'tuned' in the solid state? This appeared to me to be an ideal basis on which to build a chemical biological complement to current zeolite research work but instead of a zeolite to use carboxypeptidase A in a stabilised crystalline phase to tune catalytic activity between the two functions (protease and esterase) using controlled ionexchange processes, so I went ahead and wrote the full proposal.

In retrospect I think it was entirely fair for Glyn to have set this formidable challenge before me and I have always been grateful to both Glyn and Alan for doing this - it really changed my life, expanded my interests and helped me to grow up. I am glad to report that both Glyn and Alan were delighted with the result when I presented the proposal six weeks later and so began three very happy years working positively for and with both Glyn and Alan, resulting finally in six publications. I spent these three years working in the Cockcroft Building, just where Craig worked some twenty years later, but happily without my ever needing to be stripped, scrubbed and decontaminated with EDTA as he so vividly describes! Fortunately Salford University was stunningly well-equipped in those days, not only having extensive radiochemical facilities within the Cockcroft building but also dedicated isolated 'cold rooms', controlled to just above freezing point, where I had to spend many a long hour dialysing and recrystallising my very precious and expensive enzyme fractions wrapped up in an overcoat and gloves!

Space does not allow me to describe in any detail the many ways that Alan continued to support and encourage me as I pursued my career over the following years. Here are just a few details to demonstrate the point:

Just before final year of my $\mathrm{PhD}$ studies I fell seriously ill for three months with viral encephalitis. On being informed of my illness, the SRC sent a letter expressing best wishes for my recovery but cancelling my financial support until further notice (!). Alan not only personally sorted this out for me when I was in no state to fight my corner by not only getting the grant support reinstated, but also extended. Meanwhile he kept in personal touch with Patricia and my parents in London to reassure them during my confinement and convalescence.

Alan told me that he wanted me to present a major paper on his group's work at the next International Conference on Zeolites in Zurich in 1973, generously forgoing his exposure in order to raise my profile. This not only made me known to leading international scientists in the zeolite community at that time but it also undoubtedly helped me to obtain a Lectureship at City University in late 1974, immediately after my three year post-doctoral fellowship ended at Imperial College.

Concerning my post-doctoral studies at Imperial College with Prof Richard M Barrer FRS (sometimes described as 'the father of zeolite chemistry') I learnt later from that one key factor in my being hired was the personal reference about me given to Richard by Alan.

Even as I slowly moved out of zeolite chemistry and especially after I left academe to join Unilever Research as Principal Scientist in the later ' $80 \mathrm{~s}$, Alan continued to want to work with me and for us to publish together. Thus I was co-author with him and Hassan Enamy in the early eighties and then in the nineties he not only pressed for me to have a visiting professorial position at Salford but for me to co-supervise with him one of his PhD students from Finland, Risto Harjula, known now to many in the BZA community for his brilliant work on ion exchange in zeolites, until his sad and untimely death in 2017 ended a close friendship we had had for some 25 years. The initial supervisory collaboration, led by Alan, resulted in a further 7 joint papers and helped me to open up my collaborations with the Helsinki Chemical Forum and in Brussels with Cefic and the European Commission on the EU REACH programme, and the European Technology Platform on the bio-economy and sustainable chemistry and biotechnology, which it was my honour to chair from 2007 to 2010. It was a very special honour therefore for Risto and me to both be invited to give lectures in celebration of Alan's $80^{\text {th }}$ birthday at the IZA meeting in 2014, organised in Glasgow.

There is so much more that I could add but I will stop there. Craig finished his tribute by saying, "Alan to me was my supervisor and mentor but most importantly my friend". I wholeheartedly concur; Patricia and I will never forget him and we also thank you, Dilys, for all the support that you gave him and us throughout the years.

Rodney Townsend PhD DIC ARCS CChem FRSC

Amongst the amateur mineral collector community Alan is perhaps best remembered as President of the Russell Society from 2005-2009 and as a member of the British Micromount Society for many years.

His interest in natural zeolites encouraged him to undertake many field excursions both for his own research purposes and also as a 
means of introducing others to the subject. He could also be found each September at the British Micromount Symposium in Leicester, scouring the benches for potentially interesting specimens and giving delegates the benefit of his encyclopaedic knowledge on zeolites, and much valued access to analytical equipment and expertise.

In addition to his many professional / academic publications Alan also found time to assist amateur mineralogists with their studies and jointly authored a number of papers with fellow collectors (Braithwaite et al., 2001; Dyer et al., 2001; Dyer et al., 2003; Dyer et al., 2005; Dyer et al., 2006; Wilson et al., 2008; Dyer et al., 2014). He also regularly reviewed papers for the Journal of the Russell Society and served on its editorial board.

Alan co-authored two of the British Micromount Society's popular Occasional Paper series - no. 15. Zeolites of the British Isles jointly with Oneta Wilson and Hassan Enamy, and no. 19. Zeolites of the World (excluding British Isles) with Oneta Wilson.

A familiar face at UK mineral shows and events he will be sadly missed amongst the collector community, especially so amongst the many enthusiasts for zeolites.

Roy Starkey

\section{References}

Braithwaite R.S.W., Dyer A. Lamb R.P.H. and Wilson J.I. (2001) Gismondine- $\mathrm{Ba}$, a zeolite from the weathering of slag. Journal of the Russell Society, 7, 83-85.

Dyer A., Wilson O.M. and Young B. (2001) Natrolite from Calton Hill, Derbyshire, England. Journal of the Russell Society, 7, 89.

Dyer A., Waughman R. and Williams C. (2003) Calcium analcime from The Totherick, Ayrshire, Scotland: An unusual crystal form with trapezoidal faces. Journal of the Russell Society, 8, 26-29.

Dyer A., Green D.I., Taylor B. and Williams C.D. (2005) A tin-lead alloy found in a zeolitic amygdale at Carsaig Bay on the Hebridean Isle of Mull. Journal of the Russell Society, 8, 113-114.

Dyer A., Green D.I., Tindle A.G. and Williams C.D. (2006) Clinoptilolite and heulandite from Wheal Hazard, St Just, Cornwall. Journal of the Russell Society, 9, 68-72.

Dyer A., Green D.I. and Williams C.D. (2014) Kinoshitalite from Bennalt Manganese Mine, Rhiw, Pen Llŷn, Gwynedd, Wales: a first British occurrence. Journal of the Russell Society, 17, 30-32.

Wilson O.M., Dyer A., Holyer V.A.D. and Williams C.D. (2008) Scolecite from Cornwall, the first occurrences in England. Journal of the Russell Society, 11, 87 . 